\title{
CrimRxiv
}

\section{Memorandoms by James Martin: An Astonishing Escape from Early New South Wales}

\section{Tim Causer}

Published on: Mar 04, 2022

License: Creative Commons Attribution 4.0 International License (CC-BY 4.0). 
